\title{
Leopard range size and conservation area size in the southern Kalahari
}

\author{
Authors: \\ Jacobus du P. Bothma ${ }^{1}$ \\ Marius D. Bothma \\ Affiliations: \\ ${ }^{1}$ Centre for Wildlife \\ Management, University of \\ Pretoria, South Africa \\ ${ }^{2}$ Halls Head, Mandurah, \\ Australia \\ Correspondence to: \\ Jacobus Bothma \\ Email: \\ kobus.bothma@vodamail. \\ co.za \\ Postal address: \\ PO Box 2726, George 6530, \\ South Africa \\ Dates: \\ Received: 23 Feb. 2012 \\ Accepted: 09 July 2012 \\ Published: 11 Oct. 2012 \\ How to cite this article: \\ Bothma, J. du P. \& Bothma, \\ M.D., 2012, 'Leopard range \\ size and conservation \\ area size in the southern \\ Kalahari', Koedoe 54(1), \\ Art. \#1076, 4 pages. http:// \\ dx.doi.org/10.4102/koedoe. \\ v54i1.1076
}

C 2012. The Authors. Licensee: AOSIS OpenJournals. This work is licensed under the Creative Commons Attribution License.
The range use patterns of adult leopards were used to examine the impact of environmental quality on conservation area size in the arid south-western portion of the Kgalagadi Transfrontier Park in southern Africa. The ranges of the leopards are the largest recorded in the world, with a mean size of $2104.4 \mathrm{~km}^{2}\left(\mathrm{SE}_{\mathrm{M}} 995.95 \mathrm{~km}^{2}\right)$ for males and $1258.5 \mathrm{~km}^{2}$ $\left(\mathrm{SE}_{\mathrm{M}} 541.50 \mathrm{~km}^{2}\right)$ for females. Overlaps in range use within and between the sexes and the size of this conservation area make it possible to sustain a genetically viable population of leopards in this arid environment.

Conservation implications: When establishing conservation areas that contain large carnivores in arid and semi-arid regions, prey abundance and range use should be considered for the area to be able to sustain viable populations of such carnivores. The results emphasise the importance of establishing large transfrontier conservation areas where individual conservation areas are too small to do so. This study is the first to do so for leopards in southern Africa.

\section{Introduction}

Opportunistically hunting apex predators such as the large cats will hunt every prey animal that is encountered and their survival is therefore dependent on prey abundance and geographic distribution, which are a reflection of habitat quality through environmental conditions such as rainfall and ambient temperature (Coe, Cumming \& Phillipson 1976; Sunquist \& Sunquist 2002). Consequently, the size and location of a conservation area will affect its ability to support genetically viable populations of leopards, Panthera pardus. Range use by the females of large solitary felids depends on prey abundance and distribution whilst that of males depends on the geographic distribution of females and is a product of social behaviour (Sunquist \& Sunquist 2002). It is therefore expected that the ranges of the leopard in semi-arid and arid regions will be larger than in mesic ones and that behavioural adaptations such as range use overlap between adult males may impact on viable leopard conservation area size, because if the ranges of the leopards did not overlap, as happens in many mesic regions, it would require larger conservation areas to sustain a genetically viable leopard population. In the prey-rich equatorial forests at the edge of the Chitwan National Park in Nepal, for example, the ranges of adult male leopards are exclusive and small (mean size: $10 \mathrm{~km}^{2}$ ) (Seidensticker, Sunquist \& McDougal 1990), whilst in the savannas of the more semi-arid Kruger National Park the ranges are larger (mean size: $25 \mathrm{~km}^{2}$ ) and there is a mean overlap of $19 \%$ in range use by the adult males (Bailey 1993). In the most arid, south-western part of the Kgalagadi Transfrontier Park the ranges of leopards are the largest recorded globally, but range use overlaps and core area range use sizes were not indicated by Bothma et al. (1997). Because leopards are socially solitary animals, it is also expected that an adult male will only make contact with an adult female when she is in oestrus.

According to Prof. B. Jansen van Vuuren (Genetics Laboratory, Department of Zoology, University of Johannesburg, pers. comm., 05 June 2012) it was previously believed that a minimum population size of 500 animals was required to maintain a genetically viable population. However, it is now recognised that this will depend on many aspects, including genetic heterogeneity and speciesspecific traits, although the absolute minimum population should preferably not be less than 50 breeding animals. Nevertheless, at the time of its declaration in 1931, the Addo Elephant National Park contained only 11 elephants, Loxodonta africana, whilst this population now numbers in excess of 700 animals (Preller 2008).

Three hypotheses were briefly studied here. The first was that the ranges of leopards in the most arid south-western portion of the Kgalagadi Transfrontier Park will be larger than in mesic regions. The first was that the ranges of leopards in the arid south-western portion of the Kgalagadi Transfrontier Park will be large. The second that behavioural adaptations such as range use overlap by adult males may impact on the viability of the size of this conservation area 
for leopards. The third was that an adult male and female would probably only make contact when she was in oestrus.

\section{Study area}

The Kgalagadi Transfrontier Park is a combination of the Kalahari Gemsbok National Park of South Africa $\left(9591 \mathrm{~km}^{2}\right)$ and the Gemsbok National Park of Botswana $\left(28400 \mathrm{~km}^{2}\right)$ and hence has a surface area of $37991 \mathrm{~km}^{2}$. The ambient temperature and annual rainfall vary greatly, with daytime temperatures as low as $-10.3{ }^{\circ} \mathrm{C}$ and as high as $45.4{ }^{\circ} \mathrm{C}$ in the south-western region. The erratic annual rainfall has a mean of $185 \mathrm{~mm}$ in the south-western, and $450 \mathrm{~mm}$ in the north-eastern regions. The variable, and often localised, rainfall affects primary productivity and causes the larger herbivorous mammals (potential leopard prey) to be distributed unevenly in time and space (Bothma \& Mills 1977; Mills \& Retief 1984; Van der Walt et al. 1984; Van Rooyen et al. 1990). There are 20 landscapes in the Kalahari Gemsbok National Park, with dunes featuring prominently in many of them (Van Rooyen et al. 2008). This study was conducted in the most arid south-western portion of the Kgalagadi Transfrontier Park.

\section{Research method and design}

The range sizes that were calculated by Bothma et al. (1997) were based on very high frequency (VHF) radio-collar locations that were analysed with early kernel methods for 95\% (total range use) and 50\% (core area of use) isopleths. To standardise these according to currently accepted approaches (Börger et al. 2006), the original data were re-analysed with the ArcView 3.2 Version 1.1 and the Animal Movement Extension to ArcView software (http://esri/software/ arcgis/arcview) of Hooge and Eigenlaub (1997) and by using $90 \%$ and $50 \%$ isopleths respectively. The data are based on the geographic locations of three adult males from 10 June 1988 to 16 November 1989 and five adult females from 15 October 1987 to 11 October 1992 (Bothma et al. 1997).

In addition, global positioning system (GPS) data on three adjacent adult males and two females later became available for range use overlap studies. The locations of an adult male and female relative to each other were then also recorded daily from 14 November 2000 to 03 April 2001 after they were collared on the same day, $15.8 \mathrm{~km}$ apart. These and all the more recent location fixes were based on the use of Earthspan satellite GPS radio-collars that were linked to an Argos satellite. Only those locations with a location fix accuracy of $350 \mathrm{~m}$ or less were used in these analyses.

\section{Results}

Maps of the original localities of occurrence of the leopards studied over time appear in Bothma et al. (1997) and will not be repeated here. The re-analysed range use data yielded a mean total range size of $2104.4 \mathrm{~km}^{2}$ (Standard Error of the Mean $995.95 \mathrm{~km}^{2}$ ) for adult males and $1258.5 \mathrm{~km}^{2}$ $\left(\mathrm{SE}_{\mathrm{M}} 541.50 \mathrm{~km}^{2}\right)$ for females, as opposed to means of $2182.4 \mathrm{~km}^{2}\left(\mathrm{SE}_{\mathrm{M}} 283.49 \mathrm{~km}^{2}\right)$ and $1488.3 \mathrm{~km}^{2}\left(\mathrm{SE}_{\mathrm{M}} 665.61 \mathrm{~km}^{2}\right)$ respectively in the earlier study of Bothma et al. (1997). The mean core area of range use for the adult males was $499.9 \mathrm{~km}^{2}$ $\left(\mathrm{SE}_{\mathrm{M}} 297.40 \mathrm{~km}^{2}\right)$ and $292.4 \mathrm{~km}^{2}\left(\mathrm{SE}_{\mathrm{M}} 145.59 \mathrm{~km}^{2}\right)$ for the females, but core areas of range use were not calculated by Bothma et al. (1997). There was a mean overlap of $48.3 \%$ $\left(\mathrm{SE}_{\mathrm{M}} 18.67 \%\right)$ of range use by three adult males and one of $30.6 \%$ by two adult females. The three males used a mean of $30.0 \%\left(\mathrm{SE}_{\mathrm{M}} 8.15 \%\right)$ of the ranges of two females and the two females one of $51.6 \%$ of the ranges of the three males.

The adult male and female that were GPS-collared close to each other yielded 388 accurate location fixes for the male and 618 for the female. The collar of the male stopped functioning on 03 April 2001 and data gathering for the female ceased on 14 July 2001. On four of the 104 days of study, these locations were within $100 \mathrm{~m}$ of each other (well within the margin of error of the location fixes that were used) or concurred. These incidents were 33, 35, 35 and 37 days apart, with a mean interval of 35.0 days ( $\mathrm{SE}_{\mathrm{M}} 0.82$ days). They all occurred within a $294.5 \mathrm{~km}^{2}$ portion $(27.2 \%)$ of the total range of $1082.5 \mathrm{~km}^{2}$ that was used by the male during the 104 days of daily satellite tracking. Three of the four incidents were within the area of overlap between the ranges of the male and female. In the exception, the female had moved deeper into the range of the male. One incident was in the core area of range used by the female and two in the core area of range used by the male. On the days before possible contact, the male and female were a mean of $3.1 \mathrm{~km}$ apart $\left(\mathrm{SE}_{\mathrm{M}} 0.96 \mathrm{~km}\right)$, and on the days following such an incident, one of $8.2 \mathrm{~km}$ $\left(\mathrm{SE}_{\mathrm{M}} 1.50 \mathrm{~km}\right)$ apart. On the other 98 days of the study, they were a mean of $17.4 \mathrm{~km}\left(\mathrm{SE}_{\mathrm{M}} 0.93 \mathrm{~km}\right)$ apart.

The above-mentioned male and female leopards did not use all parts of their total ranges or the core areas of these ranges every month. For the four months that data were available, the male used a mean of $72.1 \%\left(\mathrm{SE}_{\mathrm{M}} 9.58 \%\right)$ of his total range and $77.4 \%\left(\mathrm{SE}_{\mathrm{M}} 6.30 \%\right)$ of his core area of range per month. For the eight months that data were available for the female, she used a mean of $43.4 \%\left(\mathrm{SE}_{\mathrm{M}} 11.18 \%\right)$ of her total range and $54.5 \%\left(\mathrm{SE}_{\mathrm{M}} 15.15 \%\right)$ of her core area of range per month.

\section{Ethical considerations}

The leopards were collared by staff of South African National Parks, South Africa, according to national and international guidelines that existed there and at the University of Pretoria at the time of the study. The project was formally approved by the then South African National Parks Board. No formal ethical protocols were applicable at the time of the research for the Univeristy of Pretoria or the South African National Parks. No students or other field researchers were involved in collecting the data because the data were downloaded from orbiting satellites. The leopards were darted and fitted with GPS radio collars according to accepted norms and were not approached or handled subsequently. The staff involved had the medical benefits of their organisation. The data used here were only used by the authors.

\section{Trustworthiness}

The results and conclusions drawn are based on the observations of the senior author who conducted the 
data interpretation following the Geographic Information Systems (GIS) analysis.

\section{Reliability}

The techniques used are generally accepted for repetitive range use studies at a given time although it is recognised that changing environmental conditions can yield variations in it. This is a normal ecological occurrence. However, the same general pattern of range use will emerge even if the specific data were to change to some degree. It is the pattern and not the specifics which is important to generalise the theory.

\section{Validity}

The hypotheses that were tested and accepted validate the generalised theories that were developed.

\section{Discussion}

Whilst the use of kernel estimates for range use calculation was questioned by Hemson et al. (2004), subsequent studies have confirmed that it is an efficient method to do so provided that $90 \%$ isopleths are used to estimate the total area of range use and $50 \%$ isopleths to estimate the core area of range use (Börger et al. 2006). However, the minimum convex polygon method should rather not be used (Nilsen, Pedersen \& Linnell 2008). In the current study, the data that were derived from VHF and GPS tracking were not combined because of possible biases when using two different methods to collect the data.

The mean interval of 35 days between possible contacts between the male and female fits the known mean interoestrus period of 46 days (range: 20-55 days) in leopards (Sadleir 1966). This seems to indicate that an adult male and female leopard will only make contact when the female is in oestrus.

Given the mean range use overlap that was found within the leopard sexes in this study, the Kalahari Gemsbok National Park portion of the Kgalagadi Transfrontier Park is expected to be able to support 10 adult males and 25 adult females (total population: 35) whilst the Gemsbok National Park is expected to be able to support 37 adult male and 99 adult female leopards (total population: 136). The combined conservation area therefore seems to be large enough to support 171 adult leopards, which is more than the proposed minimum population of 50 leopards to maintain a genetically viable population, but the Kalahari Gemsbok National Park portion alone cannot do so. However, the leopard population in the Kgalagadi Transfrontier Park may well be larger, because the study was done in the most arid south-western portion, whilst Funston (2001) found 4.5 times more leopard tracks in the north-eastern part of this park than in the south-western portion. This difference could be linked to an expected higher primary productivity (Coe et al. 1976) in the north-eastern portion because the rainfall in this park increases from the south-west to the north- east. Therefore, the real population size of leopards in the Kgalagadi Transfrontier Park may potentially be greater than when it is based only on the data from the south-western portion of it. Moreover, the extent of range use overlap of possible uncollared leopards in the study is unknown.

The large variations in range size and use that were found made valid statistical analyses of the means impossible to calculate because they led to large standard deviations and errors of the means. Moreover, it is extremely difficult to find and collar all the possible leopards in a study of range use in the vast and largely trackless southern Kalahari. Because prey distribution and abundance appear to determine the range size of adult female leopards and their range sizes will influence those of the males, the range use by leopards in the Kgalagadi Transfrontier Park must respond over time to the rainfall variations that affect the abundance and distribution of the larger herbivore prey (Bothma \& Mills 1977, Mills \& Retief 1984, Van der Walt et al. 1984; Van Rooyen et al. 1984). Although leopards also prey on a wide range of other prey, their main prey animals are herbivores in the size range from $20 \mathrm{~kg}$ to $70 \mathrm{~kg}$ (Bothma \& Le Riche 1984, 1986, 1994).

\section{Conclusion}

The range sizes and range use overlaps of the leopards in the southern Kalahari are the largest recorded in the world. Because leopards occur in a wide range of habitats, the size of conservation areas that contain leopards should take the variation in their range size use in various habitats into consideration so as to ensure that they can contain genetically viable populations. Adaptations in social behaviour such as the within-sex range use overlap that is found in prey-poor, arid regions make it possible for the prey-poor conservation areas such as the Kgalagadi Transfrontier Park to support a larger leopard population than would be the case if no range use overlaps occurred. This study therefore confirms the value of creating large conservation areas, especially in arid regions, where large felids occur.

The results support the hypotheses that the ranges of leopards in semi-arid and arid regions are larger than in mesic ones and that behavioural adaptations such as range use overlap between adult males may impact on viable conservation area size for leopards because they would have had to have been larger if no overlaps occurred. The admittedly small sample size of the distance and contact between an adult male and female within her oestrus cycle also confirms the extensive spoor tracking data, which showed that adult leopards in the southern Kalahari are largely solitary and that they only make contact when a female is in oestrus (Bothma \& Le Riche 1995).

The study opens up an interesting avenue of future research. A study of leopard range use at selected intervals along the rainfall gradient from the more arid south-western to the wetter north-eastern region of this park, combination with prey distribution and abundance studies and genetic analyses of the leopards, should more conclusively 
indicate the influence of this environment on leopard range use. It should also confirm whether the Kgalagadi Transfrontier Park contains a genetically viable leopard population or not. A study of the range use by leopards at selected intervals along the more arid south-west to wetter north-east rainfall gradient will enable the more accurate calculation of the leopard population in this park. A similar study of prey abundance and distribution will explain the range use patterns more clearly. Genetic analyses will be conservationally important. In combination, these studies will help to determine whether this transfrontier park can sustain a genetically viable leopard population or not.

\section{Acknowledgements}

The capture and radio-collaring of the leopards in this study occurred under strict supervision of trained staff of the South African National Parks and followed the ethical code of that organisation and of the University of Pretoria. The South African Natural History Unit of Route 66 Films allowed the use of some satellite radio-collar data. Funding was received from the University of Pretoria and Shayamanzi Game (Pty) Ltd (http://www.leopard.tv/index.php). The then Warden E.A.N. Le Riche gave valuable field support and B. Bothma typed numerous drafts of the manuscript. We sincerely thank them all.

\section{Competing interests}

The authors declare that they have no financial or personal relationship(s) which may have inappropriately influenced them in writing this paper.

\section{Authors' contributions}

J. du P.B. (University of Pretoria) was the project leader, was responsible for the project design, did the field research, collected the satellite GPS location details, analysed and interpreted the results and wrote the manuscript, whilst M.D.B. (Halls Head) did the ArcView and GIS analyses.

\section{References}

Bailey, T.N., 1993, The African leopard, Columbia University Press, New York.

Bothma, J. du P. \& Le Riche, E.A.N., 1984, 'Aspects of the ecology and behaviour of the leopard Panthera pardus in the Kalahari Desert', Koedoe (Supplement) 27 259-279. http://dx.doi.org/10.4102/koedoe.v27i2.585
Bothma, J. du P. \& Le Riche, E.A.N., 1986, 'Prey preference and hunting efficiency of the Kalahari Desert leopard', in S.D. Miller \& D.D. Everett (eds.), Cats of the world: Biology, conservation and management, pp. 389-414, National Wildlife world: Biology, conservation
Federation, Washington, D.C.

Bothma, J. du P. \& Le Riche, E.A.N., 1994, 'Scat analysis and aspects of defecation in northern Cape leopards', South African Journal of Wildlife Research $24(1 \& 2)$, 21-25.

Bothma, J. du P. \& Le Riche, E.A.N., 1995, 'Evidence of the use of rubbing, scentmarking and scratching posts by Kalahari leopards', Journal of Arid Environments 29, 213-219.

Bothma, J. du P. \& Mills, M.G.L., 1977, 'Ungulate abundance in the Nossob River Valley, Kalahari Desert', in T.J. Peterle (ed.), Proceedings of the XIIIth International Congress of Game Biologists, The Wildlife Institute, Washington D.C., Atlanta, March 10-15, 1977, pp. 90-102.

Bothma, J. du P., Knight, M.H., Le Riche, E.A.N. \& Van Hensbergen, H.J., 1997, 'Range size of southern Kalahari leopards', South African Journal of Wildlife Research 27(3), 94-99.

Börger, L., Franconi, N., De Michele, C., Gantz, A., Meschi, F., Manica, A. et al., 2006, 'Effect of sampling regime on the mean and variance of home range size', Journal of Animal Ecology 75, 1393-1405, viewed 15 May 2012, from http://www.zoo. com.uk/zoostaff/manica/ms/2006_Borger_et_al_J_Anim_Ecol.pdf

Coe, M.J., Cumming, D.H.M. \& Phillipson, J., 1976, 'Biomass production of large herbivores in relation to rainfall and primary production', Oecologia 22, 341-354, viewed 15 May 2012, from http://www.deepdyve.com/lp/Springer-journals/ biomass-and-production-of-large-african-herbivores-in relation-to-9Gm4lg2DhC

Funston, P., 2001, Kalahari transfrontier project: Final report, Endangered Wildlife Trust, Parkview.

Hemson, G., Johnson, P., South, A., Kenward, R., Ripley, R. \& Macdonald, D., 2004, 'Are kernels the mustard? Data from global positioning system (GPS) collars suggest problems for kernel home-range analyses with least squares cross validation', problems for kernel home-range analyses with least squares cross validation,' onlinelibrary.wiley/com/doi/10.1111/j.1365-2656.2005.00944.x

Hooge, P.N. \& Eigenlaub, B., 1997, Animal movement extension to ArcView Version 1.1, Anchorage, Alaska Biological Science Center, U.S. Geological Survey.

Mills, M.G.L. \& Retief, P.F., 1984, 'The response of ungulates to rainfall along the riverbeds of the southern Kalahari', Koedoe (Supplement) 27, 129-141. http:// dx.doi.org/10.4102/koedoe.v27i2.574

Nilsen, E.B., Pedersen, S. \& Linnell, J.D.C., 2008, 'Can minimum convex polygon home ranges be used to draw biologically meaningful conclusions?', Ecological Research 23, 635-639. http://dx.doi.org/10.1007/s11284-007-0421-9

Preller, B., 2008, The silent giants of southern Africa (Loxodonta africana), 2nd edn., Bob Preller, Wilderness.

Sadleir, R.M.F.S., 1966, 'Notes on reproduction in large Felidae', International Zoo Yearbook 6, 184-187, viewed 15 May 2012, from http://www.onlinelibrary.wiley. com/doi/10.1111/izy.1966.6.issue-1/issuetoc

Seidensticker, J., Sunquist, M.E. \& McDougal, C., 1990, 'Leopards living at the edge of Royal Chitwan National Park, Nepal', in J.D. Daniel \& J.S. Serrao (eds.) Conservation in developing countries: Problems and prospects, pp. 415-423, Bombay Natural History Society, Bombay.

Sunquist, M. \& Sunquist, F., 2002, Wild cats of the world, Chicago University Press, Chicago.

Van der Walt, P.T., Retief, P.F., Le Riche, E.A.N., Mills, M.G.L. \& De Graaff, G., 1984 'Features of habitat selection by large herbivorous mammals and the ostrich in the southern Kalahari conservation area', Koedoe (Supplement) 27, 119-128. http://dx.doi.org/10.4102/koedoe.v27i2.573

Van Rooyen, N., Bezuidenhout, D.J., Theron, G.K. \& Bothma, J. du P., 1990, 'Monitoring of the vegetation around artificial watering points (windmills) in the Kalahari Gemsbok National Park', Koedoe 33, 63-88. http://dx.doi.org/10.4102/koedoe. v33i1.453

Van Rooyen, M.W., Van Rooyen, N., Bothma, J. du P. \& Van den Berg, H.M., 2008 , 'Landscapes in the Kalahari Gemsbok National Park', Koedoe 50(1), 99-112. http://dx.doi.org/10.4102/koedoe.v50i1.154 